JCMS

6,1

90

Received 29 November 2021 Revised 25 December 2021 Accepted 11 January 2022

\section{A comparison of international market indices for measuring market efficiency based on price-volume relationship}

\author{
Sunay Çıralı \\ Business Administration, Doğuş University, Istanbul, Turkey
}

\begin{abstract}
Purpose - The main purpose of the research is to determine if the relationship between trading volume and price changes is connected to market effectiveness and to use the volume-price relationship to compare the efficiency levels of foreign markets. The degree of the relationship is determined in this study, and the efficiency levels of different countries' capital markets are compared.

Design/methodology/approach - In this study, 1,024 observations are used as a data set, which includes daily closing prices and trading volume in the stock market indices of 25 countries between the dates of 01.12.2016 and 31.12.2020. In the first step of the analysis, descriptive statistics of price and volume series are examined. The stationarity of the series is then controlled using the ADF unit root test. Simple linear regression models with the dependent variable of trading volume are generated for all stock market indices after each series has reached stationarity, and the ARCH heteroscedasticity test is used to determine whether these models contain the ARCH effect. Because all models have the ARCH effect, autoregressive models are chosen, and EGARCH models are conducted for all indices to see whether there is an asymmetry in the price-volume relationship.
\end{abstract}

Findings - The study concludes that the stock market in the United States is the most effective, since it has the strongest relationship between trading volume and price changes. However, because of the financial distress caused by the COVID-19 pandemic, the relationship between price and trading volume is lower in Eurozone countries. The price-volume relationship could not be observed in some shallow markets. Furthermore, whereas the majority of countries have a negative relationship between price changes and transaction volume, China, the United Arab Emirates and Qatar have a positive relationship. When prices rise in these countries, investors buy with the sense of hope provided by the optimistic atmosphere, and when prices fall, they sell with the fear of losing money.

Research limitations/implications - The study's most significant limitation is that it is difficult to ascertain a definitive conclusion about the subject under investigation. In reality, if the same research is done using data from different countries and time periods, the results are quite likely to vary.

Practical implications - As a result of the study, investors can decide which market to enter by comparing and analyzing the price-volume relationship of several markets. According to the study's findings, investors are advised to examine the price-volume relationship in a market before beginning to trade in that market. In this way, investors can understand the market's efficiency and whether it is overpriced.

Social implications - The relationship between price movements and trade volume gives crucial information about a capital market's internal structure. Some concerns can be answered by assessing this relationship, such as whether the market has a speculative pricing problem, how information flows to the market, and whether investment decisions are rational and homogenous. Empirical studies on modeling this relationship, on the other hand, have not reached a definite outcome. The main reason for this is that the price-to-volume relationship fluctuates depending on the market structure. The purpose of this study is to fill a gap in the literature by presenting the reasons why this critical issue in the literature cannot be answered, as well as empirical findings.

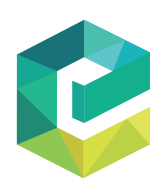

Journal of Capital Markets Studie Vol. 6 No. 1, 2022 pp. $90-105$ Emerald Publishing Limited 2514-4774

DOI 10.1108/JCMS-11-2021-0037
Originality/value - The significance and originality of this research are that it examines the price-volume relationship to evaluate the efficiency levels of various markets. This relationship is being investigated in a

(c) Sunay Çıralı. Published in Journal of Capital Markets Studies. Published by Emerald Publishing Limited. This article is published under the Creative Commons Attribution (CC BY 4.0) license. Anyone may reproduce, distribute, translate and create derivative works of this article (for both commercial and non-commercial purposes), subject to full attribution to the original publication and authors. The full terms of this license may be seen at http://creativecommons.org/licences/by/4.0/legalcode 
number of multinational studies. These researches, on the other hand, were conducted to see if there is a relationship between trading volume and market volatility, and if so, how that interaction is formed. The size of the price and volume relationship is emphasized in this study, unlike previous studies in the literature.

Keywords Price-volume relationship, Market efficiency, EGARCH, Noise trader hypothesis

Paper type Research paper

A comparison of international market

\section{Introduction}

According to the classical law of demand, the demand for a good and the price of that product have a negative relationship. In other words, in the case of Ceteris Paribus the relationship between the quantity demanded for a good and the price of that good is the basis of Marshall and Walras' law of demand. This is a negative relationship. That is, if a good's price is higher than the buyer's desire to pay for it, the buyer refuses to purchase this. In this scenario, the price of that good decreases than the price agreed upon by the buyer, and the market comes to equilibrium point.

Financial markets, on the other hand, are platforms where financial assets are bought and sold, bringing together savers and borrowers. Economic units with a deficit of savings (suppliers of financial assets) sell the financial asset on the capital markets, while economic units with excess savings (demanders of financial assets) buy the financial asset. The primary assumption of this study is that supply and demand in capital markets can be formed similarly to supply and demand in product markets.

If the law of demand is applied to the capital markets, since a stock's price falls, investors see it as a buying opportunity, and demand for that asset, as measured by trading volume, rises. When the price of a stock rises, however, investors who want to realize their profits decide to sell, reducing demand for that stock and, as a result, trading volume. Price fluctuations and transaction volume in the capital markets are expected to have a negative relationship in this circumstance.

In real life, however, such a relationship is impossible to sustain. Many parameters affect the price of a capital asset and the demand for that asset. Furthermore, a hyper-efficient market is a utopia. However, as the behavioral finance theory has demonstrated, not all market participants have equal and full information, and investors are not rational in reality.

In short, a decrease in the price and demand relationship in a capital market (which will be named as the price-trading volume relationship from now on) indicates that the market has an information asymmetry, investors do not behave consistently, or regulators participate excessively in the market. To put it another way, the market is moving away from efficiency. On the contrary, as the price-volume relationship strengthens, the market approaches the equilibrium point in a free market economy, that is, becomes more efficient.

As a result, no definitive conclusion on the subject has been obtained in empirical studies on the modeling of the price-volume relationship in the literature. The main reason for this is that the price-volume relationship varies depending on the capital market's structural characteristics and time dimensions. Investors who trade in low volatility markets and have a long planning horizon can make buy-sell decisions by following the information entering the market during periods of financial stability. In this circumstance, a strong relationship between price changes and trading volume is expected. Investors, on the other hand, cannot distinguish between information and noise in high-volatility markets where there is no financial stability. As a result, the market faces a mispricing problem. A strong price-volume relationship is not clear in this circumstance, either. In brief, the price-volume relationship in a capital market can be used to make crucial inferences about the market's internal structure.

In his study, Karpoff (1987) claims that modeling the price-volume relationship can be used to analyze the market structure and information flow. The study cites four reasons that emphasize the significance of this relationship. The first of them is determining whether new 
JCMS 6,1

92

information entering the market is homogeneously distributed by looking at the price-volume relationship. That is, the price-volume relationship changes depending on the market's information distribution and exposes whether new information is reflected in the prices. The price-volume relationship is also significant since it explains investor behavior such as dividend preferences. At the same time, the price-volume relationship demonstrates whether investors act in a rational and consistent way when interpreting information. Third, by examining the price-volume relationship, it is possible to evaluate whether or not a capital market has a speculative pricing problem. A stock is considered to be mispriced if its price is not supported by investor demand (which in this case means trading volume). Mispricing of capital assets can be found in this scenario by examining the price-volume relationship. By evaluating the price-volume relationship, it is possible to determine whether private and public information is reflected in investor demand. Finally, the futures markets are influenced by the price-volume relationship. As a result, volatility has an impact on futures contract trading volume.

The effect of information flow on investor demands can be observed by modeling the price-volume relationship in a market, as said by Karpoff (1987). Fama (1970) defined efficient markets as those in which all public and private information reflects asset values. According to this definition, a market is considered a strong efficient market if all available information reflects the market, and an equilibrium price and demand for capital assets occurs in this strong efficient market. An "exact" relationship between price and volume can be mentioned in this situation. However, Fama's (1970) strong efficient market describes an ideal market, it is impossible to find in real life. With the asymmetric information theory, Akerlof (1970) shows that market actors cannot always have equal and complete information. Because of the asymmetric information problem in the market, prices are not supported by demand, resulting in speculative pricing. A highly strong price-volume relationship cannot be detected in the market when all private and public information does not reflect stock prices, that is, when the assumption of equal and complete information is no longer valid. As a result, information on the market's efficiency level can be obtained by measuring the degree of the price-volume relationship. That is, in more efficient markets, the price-volume relationship is relatively strong, while in less efficient markets, it's quite weak.

The noise traders hypothesis, proposed by De Long et al. (1990), is an alternative to the efficient market hypothesis. He claims that anomalies like excessive stock price volatility and average returns can be explained by noisy traders risk in his study. The hypothesis's basic principle is that arbitrage loses its attractiveness due to the risk posed by the unpredictability of noisy traders' ideas. As a result, investors have a short planning horizon and are worried about losing profits on a mispriced product. As a result, even if there is no fundamental danger in the market, an investor's credit risk is constrained. Irrational investor behavior is characterized by "unpredictability," and most professional investor activity is a result of noisy trading. Professional traders spend their time researching and forecasting the fake signals that noisy traders are tracking in such an environment. In summary, the prevalence of false signals in the market, referred to as noise, as well as the irrationality of investors cause price movements to be unsupported by trading volume. New information entering the market is not reflected in prices and trade volume at the same time, according to the noise trades hypothesis. As a result, price and volume do not have a bidirectional relationship. The trading volume reflects price changes in response to new information entering the market. In other words, this strategy assumes that there is a one-way positive relation from price to volume.

In conclusion, if the degree of relationship between trading volume and price changes is strong, this market has a low rate of speculation and is a relatively more efficient market. If the degree of the relationship is low, it indicates that market efficiency is still low. This research compares the degree of relationship between trading volume and price changes in 
international capital markets to determine the efficiency levels in various nations' capital markets.

Between the dates of 01.12 .2016 and 31.12.2020, the daily closing prices and trading volume amounts of stock market indices from 25 different nations are analyzed and their volume-price relationships are compared in this study. The descriptive statistics of price and volume data are examined in the initial step of the analysis. The ADF unit root test is then used to verify the series' stationarity. Simple linear regression models with trading volume as the dependent variable are conducted for the indexes after stability control, and the models are submitted to the ARCH heterocasticity test to see if they contain the ARCH effect. Because the ARCH effect is seen in the models, it's considered that an autoregressive model should be utilized, and the EGARCH method is one of them. The EGARCH method was chosen to see if there would be a change in the relationship under consideration if prices increased or decreased.

\section{Literature review}

Despite the fact that investigating the price-volume relationship is a critical subject, there has yet to be an agreement in the research. The main reason for this is that different markets have distinct structural characteristics, and markets' internal structure evolves with time.

The mixed distributions hypothesis, proposed by Clark (1973), developed by Epps and Epps (1976) and Harris (1986), the sequential information hypothesis proposed by Copeland (1976) and the noise traders hypothesis proposed by De Long et al. (1990) are the three approaches that have been used to argue that there is a positive relationship between price changes and trading volume.

According to the mixed distributions hypothesis (Clark, 1973), the variance of a transaction's price change is proportional to its trading volume. As a result, both price and volume are affected by the rate at which new information enters the market. When fresh information enters the market, both price and volume move at the same time. As a result, a new equilibrium is formed instantaneously, and no intermediate state of equilibrium exists. As a result, this assumption asserts that previous data has no bearing.

Tauchen and Pitts (1983) investigate the association between daily price volatility and trading activity in speculative markets. The model's parameters are determined by FIML, and daily data from the futures market of 90-day Treasury bills are used in the study. During the study period, large trends in trade volume were detected, and the authors claim that these trends may partially or totally obscure the price-volume relationship. Furthermore, Lee and Rui (2002) used Granger and GARCH methods to evaluate daily data from the New York, Tokyo and London stock markets, but no causal association between trading volume and returns was found in any index in this analysis.

On the other hand, Epps and Epps (1976) indicate that transaction volume can be used as an indicator to assess the mismatch between market parties since investors check reservation prices in response to new information arriving in the market. The transaction volume, in this context, measures the conflict between traders using the mixed distribution model. According to this concept, there is a positive association between trading volume and stock returns' absolute value.

Saatçioğlu and Starks (1998) use the Granger causality test to evaluate the Latin American markets and find a direct relationship from price to volume, as an example of studies in the literature arguing for a one-way relationship between price and trading volume. Ananzeh et al. (2013) use autoregressive methods to analyze data from the Amman Stock Exchange and find that trading volume has a significant impact on return volatility. Furthermore, Gazel (2017) uses the EGARCH model to analyze weekly data from the Fragile Five Nations and shows that the mixed distributions hypothesis is valid in these countries. 
JCMS

6,1

94

According to the sequential information arrival hypothesis (Copeland, 1976), new information entering the market is not given to all market players at the same time. After a succession and transition equilibrium, the ultimate equilibrium occurs. As a result of this method, current trading volume might be influenced by previous returns and vice versa. In a nutshell, the sequential information arrival theory asserts that price and volume changes have a positive two-way relationship.

This technique is supported by various studies in the literature. Using the causality test, Jain and Joh (1988) revealed a strong simultaneous link between the S\&P 500 price and trade volume variables. Silvapulle and Choi (1999) apply the causality test to the Korean Stock Exchange data and discover a two-way relationship. Zada (2021) also conducts empirical evidence showing there is a strong association between trading volume and stock returns using regression models, Granger causality test, VAR and GARCH models on the Saudi Stock Exchange. Finally, using daily data from the ISE 100 Index and the Johansen cointegration test, Nalin and Güler (2013) find that there is a long-term relationship between transaction volume and price.

In the literature, there are also some multinational studies that support the sequential information arrival hypothesis. Using daily data from stock market indices in nine countries, Chen et al. (2001) explore the price-volume relationship using the Granger and EGARCH methods and find that there is a strong association between trading volume and price in all indices. With a causality test, Assogbavi and Osagie (2006) examine the stock markets of 26 developing countries and find substantial evidence for a positive association between volume and return.

Although many studies support mixed distributions and sequential information arrival hypotheses, several studies also support the noise traders hypothesis (De Long et al., 1990) mentioned in previous section. The fundamental reason for this is that, in light of the recent global stock market crashes, it is clear that markets are ineffective, and the notion that all market information is reflected fully and evenly to market participants has become suspect. According to the noise traders hypothesis, there is a one-way relationship from prices to transaction volume.

Gökçe (2002) used the causality test to look at daily data from the ISE National 100 index and discovered a one-way relationship from price to volume. Likewise, Umutlu (2008) uses Granger and VAR analysis to examine daily data from the ISE National All Index and concludes that there is a one-way relationship from price to trading volume. Elmas and Y1ldrim (2010) also used the intraday session data of the ISE Bank Index to conduct a causality test, which demonstrated that there is a relationship form stock prices to trading volume. Çukur et al. (2012) use the Granger causality test and daily data from the ISE 100 index to find a one-way association between return and transaction volume again.

As previously stated, these three methodologies serve as the foundation for studies looking into the price-volume relationship in the literature. However, developments such as the introduction of more reliable methods, the ability to examine short-term data due to technological advancements, the introduction of behavioral finance, and as a result, the beginning to consider the human factor, led to the investigation of negative and asymmetrical price-volume relationships.

Campbell et al. (1993) used a regression model to examine NYSE and AMEX daily data and discovered that autocorrelation in stock returns was stronger on low-volume days than on high-volume days. Gebka and Wohar (2013) use the quantile regression method to look at stock index data from nine nations and discover a negative relationship in high quantiles and a positive relationship in low quantiles. Ciner (2015) uses the quantile regression method to look at the stocks of 28 US firms and finds that the relationship between trading volume and stock returns is negative in the low quantiles and positive in the high quantiles. 
Nyakurukwa (2021) investigates the Johannesburg Stock Exchange (JSE) and discovers that in stable periods, there is a causal association between stock returns and trading volume in the middle quantiles and the complete sample, but this relationship vanishes during the COVID-19 pandemic crisis. Erdem et al. (2020) conducted a study using VAR, Granger and frequency domain causality analysis to examine the price and volume data of the BIST 30 index from 2010 to 2019. The findings show that the presence of a price-volume relationship is dependent on the type of pricing data used, and that the direction of the relationship changes with frequency.

The Granger causality test and the GARCH were used by Martikainen et al. (1994) to investigate the price-volume relationship on the Helsinki Stock Exchange. The analysis concluded that, while there was no association between transaction volume and price increases between 1977 and 1982, there was a strong relationship between transaction volume and price volatility between 1983 and 1988. The report claims that this condition is the outcome of the Finnish Stock Exchange's rapid growth after 1980.

Kiran (2010) explores the data of the ISE 100 index using GARCH and TGARCH methods and concludes that the effect of trading volume on return volatility is significant but not positive. Boyacioğlu et al. (2010) subject the monthly data of the ISE 100 Index to Granger and GARCH analysis and detect a negative relationship from volume to price.

Marsh and Wagner (2004) used the GARCH-M method to evaluate stock market index data from the United States and six other nations. The price-volume relationship in the S\&P 500 index of the United States, which is the largest and most liquid stock market, is clearer than in other markets, according to the study's findings.

Furthermore, there are various studies in the literature that look at the asymmetry in the price-volume relationship based on market increase and decrease. Al-Deehani (2007) uses the distributed lag model and autoregressive models to examine data from nine stock market indexes in eight different nations and finds that prices have a stronger impact on trading volume when prices rise than when prices decrease. Chen (2012) studies monthly data from the S\&P 500 index and finds that during a bear market, there is a negative association between trading volume and stock returns, but during a bull market, there is a positive relationship.

According to Alizadeh and Tamvakis (2016), the trading volume and returns of four energy futures contracts traded on the NYMEX exchange are positively correlated when the market is backward and negatively correlated when the market is in contango. Kayalidere and Aktaş (2009) perform a regression analysis on daily data from 23 stocks in the ISE 30 and ISE 50 indices and find that there is a strong relationship between trading volume and price, but that the degree of this relationship is higher in positive return situations and lower in negative return situations. Yllanc and Bozoklu (2014) apply a causality test to daily data from the BIST 100 index and discover that there is a one-way relationship between trading volume and price volatility, as well as an asymmetry in this relationship for positive and negative shocks.

\section{Research methodology and data}

\subsection{Data, sample and analysis process}

Before beginning the analysis, the characteristics of the data set are analyzed, and it is verified whether the data's characteristic features and models created with these data are adequate as the chosen methodology for the analysis.

Between the dates of 01.12.2016 and 31.12.2020, this study used approximately 1,024 observations, which included four-year daily closing prices and trading volume amounts of stock market indices in 25 nations. The following are the countries and stock market indices that were compared in the study: 


\begin{tabular}{|c|c|c|c|c|c|c|}
\hline \multirow{5}{*}{$\begin{array}{l}\text { JCMS } \\
6,1\end{array}$} & Country & Index & Country & Index & Country & Index \\
\hline & Australia & S\&P/ASX 200 & Italy & $\begin{array}{l}\text { FTSE Italia All } \\
\text { Share }\end{array}$ & Sweden & OMX S30 \\
\hline & Austria & ATX & Japan & Nikkei 225 & Switzerland & SMI \\
\hline & Belgium & BEL 20 & Malaysia & $\mathrm{KLCI}$ & Tunisia & TUNINDEX \\
\hline & Brazil & BOVESPA & Netherlands & AEX & Turkey & BIST 100 \\
\hline \multirow[t]{5}{*}{96} & Canada & S\&P TSX & Poland & WIG 20 & UK & FTSE 100 \\
\hline & China & SSE Composite & Portugal & PSI 20 & United Arab & ADX General \\
\hline & France & CAC 40 & Qatar & QSI & Emirates & \\
\hline & Germany & DAX & South Korea & KOSPI & USA & S\&P 500 \\
\hline & Ireland & ISEQ Overall & Spain & IBEX 35 & & \\
\hline
\end{tabular}

3.1.1 Descriptive statistics. First, the data's descriptive statistics are reviewed. Table 1 presents descriptive statistics for international stock indices' price series. In England, Germany, Poland, Spain, Ireland, Canada, Austria, Belgium, Portugal, Malaysia, Qatar, Italy, United Arab Emirates, France, China and the Netherlands, the mean values of the price series are lower than the median values, and the skewness coefficients are negative, as shown in Table 1. This indicates that the series' distribution is skewed to the left. The mean values of the price series in South Korea, Brazil, Australia, Japan, Switzerland, Turkey, the United States and Sweden, on the other hand, are higher than the median values, with positive skewness coefficients. The distribution of these countries' price series is right-skewed. Tunisia has a skewness coefficient of zero and a Jarque-Bera statistic of more than 0.05 . In this

\begin{tabular}{|c|c|c|c|c|c|c|c|c|c|}
\hline Countries & Mean & Median & Max & Min & Std. dev & Skew & Kurt & $\begin{array}{c}\text { Jarque- } \\
\text { Bera }\end{array}$ & Prob \\
\hline Australia & 6079.19 & 6013.20 & 7162.50 & 4546.00 & 418.36 & 0.28 & 3.05 & 13.70 & 0.001 \\
\hline & 2957.33 & 3050.92 & 3688.78 & 1630.84 & 420.58 & -0.82 & 2.74 & 116.12 & 0.000 \\
\hline Belgium & 3672.78 & 3709.84 & 4198.31 & 2528.77 & 290.43 & -0.80 & 3.69 & 133.10 & 0.000 \\
\hline Brazil & 86739.19 & 85602.50 & 119527.60 & 57110.99 & 16002.23 & 0.08 & 1.94 & 47.89 & 0.000 \\
\hline Canada & 15894.75 & 16016.02 & 17944.06 & 11228.49 & 851.57 & -0.83 & 6.11 & 527.88 & 0.000 \\
\hline China & 3062.36 & 3095.18 & 3559.47 & 2464.36 & 247.76 & -0.33 & 2.19 & 45.21 & 0.000 \\
\hline France & 5241.80 & 5286.57 & 6111.24 & 3754.84 & 374.40 & -0.36 & 3.72 & 45.81 & 0.000 \\
\hline Germany & 12266.86 & 12360.58 & 13790.29 & 8441.71 & 831.37 & -1.02 & 4.75 & 309.54 & 0.000 \\
\hline Netherlands & 544.49 & 546.12 & 629.23 & 404.10 & 35.43 & -0.17 & 3.55 & 18.49 & 0.000 \\
\hline Italy & 23006.67 & 23265.27 & 27675.06 & 16286.37 & 1982.91 & -0.43 & 2.95 & 32.56 & 0.000 \\
\hline Ireland & 6501.96 & 6598.67 & 7552.90 & 4366.53 & 525.96 & -0.85 & 3.84 & 154.94 & 0.00 \\
\hline Japan & 21667.10 & 21739.78 & 27568.15 & 16552.83 & 1774.29 & 0.28 & 3.42 & 20.60 & 0.000 \\
\hline Malaysia & 1666.04 & 1679.34 & 1895.18 & 1219.72 & 121.52 & -0.64 & 3.37 & 73.96 & 0.000 \\
\hline Poland & 57246.83 & 58385.25 & 67529.39 & 37164.02 & 5340.90 & -1.00 & 3.93 & 206.37 & 0.000 \\
\hline zal & 004.36 & 5131 & 5791 & 08 & 448.66 & -0.70 & 2.71 & 89. & 0.000 \\
\hline Qatar & 9701.67 & 9893.74 & 11057.83 & 7714.26 & 779.07 & -0.60 & 2.36 & 77.89 & 0.00 \\
\hline Korea & 2235.61 & & & 1457.64 & 201.58 & 0.01 & 3.33 & 4.66 & 0.097 \\
\hline Spa & 9156.8 & 9377 & 11135 & 6107.20 & 1146.13 & -0.85 & 2.90 & 125.83 & 0.000 \\
\hline Sweden & 1625.56 & 1607.25 & 1938.14 & 1292.27 & 110.74 & 0.70 & 3.38 & 89.90 & 0.00 \\
\hline Switzerland & 9401.70 & 9267.17 & 11263.01 & & & 0.34 & 2.23 & 44.25 & 0.000 \\
\hline & 741.43 & 6857.02 & & 5420 & 681 & 0.00 & 2.81 & 1.54 & 0.46 \\
\hline Turkey & 1029.50 & 1019.00 & 1479.9 & 725.20 & 121.47 & 0.48 & 3.72 & 62.16 & $0.0 c$ \\
\hline UAE & 4699.39 & 4626.95 & 5404.5 & 3323.35 & 333.47 & -0.41 & 3.27 & 31.22 & 0.00 \\
\hline UK & 7070.61 & 7279. & & & 579.46 & -1.27 & 3.63 & 296.75 & 0.00 \\
\hline USA & 2820.51 & 2790.95 & 3756.07 & 2191.08 & 344.59 & 0.51 & 2.77 & 47.04 & 0.000 \\
\hline
\end{tabular}

Table 1.

Descriptive statistics of price series of international stock indices 
situation, the series is said to have an approximately normal distribution. All series have kurtosis coefficients that are close to 3. This indicates that all series' kurtosis is near to normal.

The descriptive statistics for the transaction volume data are shown in Table 2. The skewness coefficient of all series is positive, as seen in the table. This means that the series' distribution is right-skewed. Kurtosis coefficients are much greater than 3. In other words, the series has a kurtosis distribution that is higher than normal.

3.1.2 Stability tests. The series are subjected to the augmented Dickey-Fuller (ADF) unit root test for stationarity control in this part. In unit root tests, the Schwarz Information Criteria (SIC) is employed. Table 3 presents the results of the unit root test applied to the raw data of all stock market indexes' price series. The ADF test statistics are higher than " $t$ statistics" at critical levels of 1,5 and $10 \%$, and the probability values are greater than 0.05 , as shown in the table. The hypothesis " $\mathrm{H}_{0}$ : Series includes the unit root" cannot be rejected in this situation. That is, the series is not stationary, and the first difference in the series must be taken into consideration in order to obtain consistent conclusions in the analysis' succeeding stages.

The unit root test results of the stock return series generated by calculating the first difference in closing prices are shown in Table 4 . As a result, at critical levels of 1,5 and $10 \%$, the $\mathrm{ADF}$ test statistics are lower than the $t$ statistics, and the probability values are less than 0.05. In other words, the series' stationarity is assured.

Trading volume data, as Tauchen and Pitts (1983) reported in their analysis, contain strong trends. As a result, when conducting unit root tests to transaction volume data, models that include trend and constant terms as exogenous variables must be held. The unit root test results for all indices' trade volume series are shown in Table 5. The ADF test statistics of all series are lower than the $t$ statistics at critical values of 1,5 and $10 \%$, and it is observed that

\begin{tabular}{|c|c|c|c|c|c|c|c|c|c|c|}
\hline Countries & Mean & Median & Max & Min & Std. dev & Skew & Kurt & Jarque-Bera & Prob & \\
\hline Australia & 0.656 & 0.612 & 2.380 & 0.040 & 0.230 & 2.571 & 14.186 & 6523.154 & 0.000 & \\
\hline Austria & 0.005 & 0.005 & 0.033 & 0.002 & 0.003 & 3.325 & 22.616 & 18215.030 & 0.000 & \\
\hline Belgium & 0.030 & 0.027 & 0.135 & 0.003 & 0.013 & 2.359 & 13.171 & 5463.228 & 0.000 & \\
\hline Brazil & 0.005 & 0.004 & 0.019 & 0.000 & 0.003 & 1.421 & 4.742 & 467.139 & 0.000 & \\
\hline Canada & 0.228 & 0.212 & 0.944 & 0.052 & 0.087 & 2.864 & 16.504 & 9162.396 & 0.000 & \\
\hline China & 20.726 & 18.640 & 65.780 & 8.820 & 8.716 & 1.777 & 7.111 & 1225.508 & 0.000 & \\
\hline France & 0.092 & 0.085 & 0.371 & 0.012 & 0.036 & 2.788 & 15.815 & 8487.786 & 0.000 & \\
\hline Germany & 0.095 & 0.088 & 0.413 & 0.028 & 0.037 & 2.888 & 18.109 & 11207.090 & 0.000 & \\
\hline Netherlands & 0.093 & 0.086 & 0.419 & 0.015 & 0.037 & 2.491 & 14.800 & 7129.652 & 0.000 & \\
\hline Italy & 0.793 & 0.672 & 3.750 & 0.252 & 0.397 & 2.223 & 10.635 & 3360.093 & 0.000 & \\
\hline Ireland & 0.039 & 0.026 & 0.650 & 0.002 & 0.043 & 5.416 & 53.776 & 116358 & 0.000 & \\
\hline Japan & 0.845 & 0.780 & 2.330 & 0.316 & 0.286 & 1.310 & 5.325 & 508.604 & 0.000 & \\
\hline Malaysia & 0.137 & 0.121 & 0.758 & 0.023 & 0.066 & 3.129 & 19.750 & 13295.540 & 0.000 & \\
\hline Poland & 0.049 & 0.044 & 0.220 & 0.016 & 0.021 & 2.116 & 11.406 & 3756.774 & 0.000 & \\
\hline Portugal & 0.076 & 0.065 & 0.383 & 0.008 & 0.040 & 2.057 & 10.611 & 3253.129 & 0.000 & \\
\hline Qatar & 0.034 & 0.009 & 0.364 & 0.002 & 0.049 & 2.371 & 9.519 & 2745.775 & 0.000 & \\
\hline Korea & 0.523 & 0.429 & 1.980 & 0.184 & 0.273 & 1.528 & 5.581 & 667.710 & 0.000 & \\
\hline Spain & 0.203 & 0.178 & 0.975 & 0.035 & 0.095 & 2.602 & 14.448 & 6872.985 & 0.000 & \\
\hline Sweden & 0.092 & 0.087 & 0.305 & 0.012 & 0.030 & 1.692 & 8.895 & 1971.242 & 0.000 & \\
\hline Switzerland & 0.060 & 0.054 & 0.266 & 0.016 & 0.026 & 3.121 & 18.297 & 11611.640 & 0.000 & \\
\hline Tunisia & 0.001 & 0.001 & 0.006 & 0.000 & 0.000 & 3.531 & 26.895 & 25843.030 & 0.000 & Table 2 \\
\hline Turkey & 1.706 & 1.230 & 9.460 & 0.192 & 1.255 & 2.154 & 8.454 & 2067.354 & 0.000 & Descriptive statistics of \\
\hline UAE & 0.065 & 0.051 & 0.585 & 0.007 & 0.051 & 3.461 & 24.151 & 21049.740 & 0.000 & transaction volume \\
\hline UK & 0.823 & 0.772 & 2.590 & 0.186 & 0.273 & 1.997 & 9.569 & 2541.636 & 0.000 & series of international \\
\hline USA & 3.867 & 3.604 & 9.045 & 1.297 & 1.045 & 1.992 & 8.501 & 1976.424 & 0.000 & stock indices \\
\hline
\end{tabular}

A comparison of international market

(5)




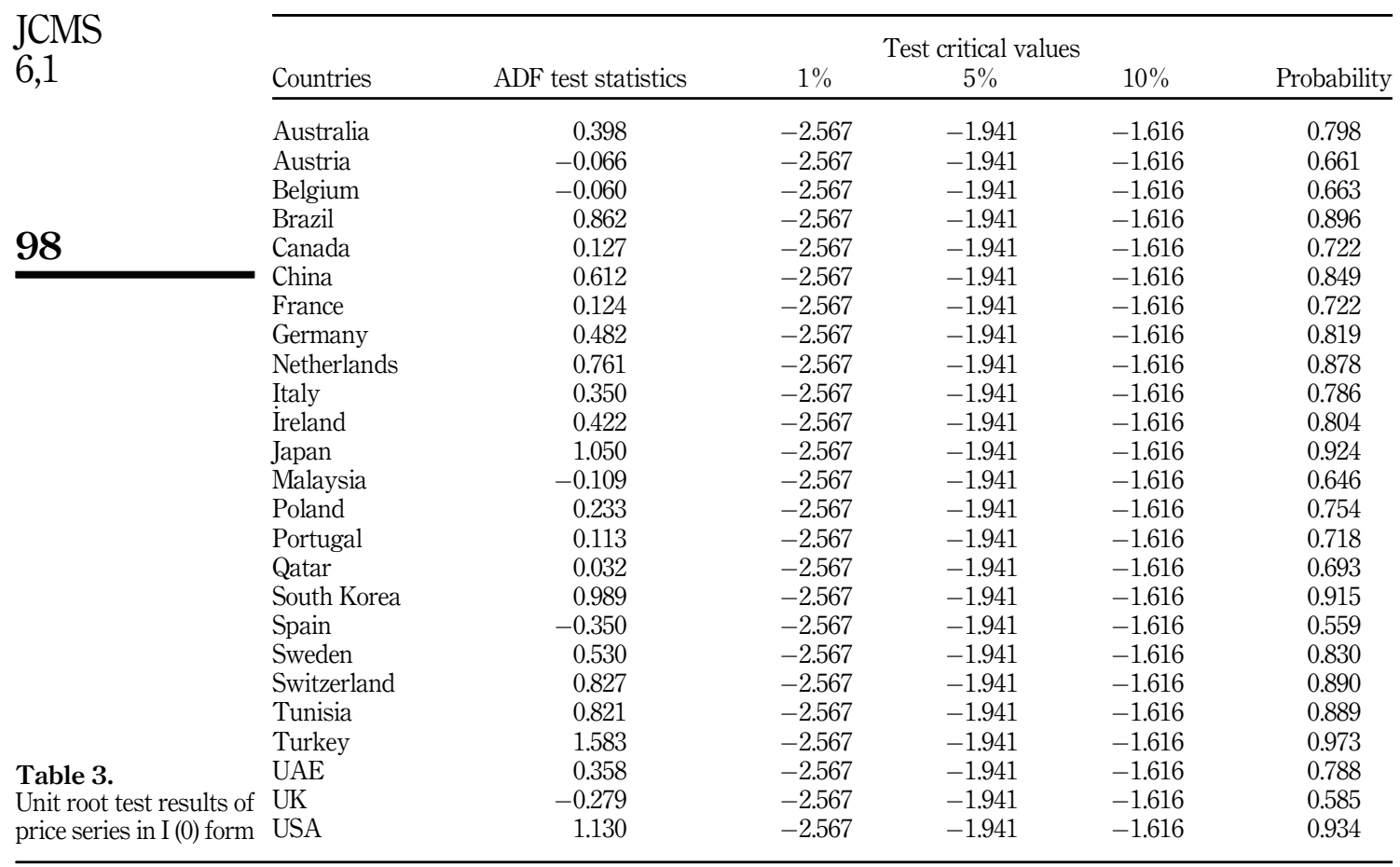

the probability values are less than 0.05 as a result of the unit root tests. In this circumstance, the raw data of the trading volume series are found to be lacking of a unit root.

3.1.3 ARCH tests. Simple linear regression models for all indices with trading volume series as a dependent variable are conducted in this part, and the ARCH Heteroscedasticity test is used to see if model variances are stable. The ARCH test results for all indices are shown in Table 6. As a result, in all models, the hypothesis " $\mathrm{H}_{0}$ : There is no ARCH effect in the model" can be rejected. In short, heteroscedasticity problems expose all models. As a result, autoregressive models should be preferred.

\subsection{Methods and empirical findings}

One of the autoregressive conditional heteroskedastic models should be utilized in the analyses, according to the previous section of the study. In this analysis, the EGARCH approach is employed to observe differences between rising and falling price scenarios. The EGARCH model is suitable for this research since it examines possible asymmetry in volatilities by taking into account the signs of the conditional variance's lagged error terms.

For each index, EGARCH models with trading volume as the dependent variable but also return volatility and constant term as the independent variables are conducted in this section of the study. The EGARCH models for all indices are shown in Table 7. As a result, in the EGARCH models of all country indices, the sum of the " $\alpha$ " and " $\beta$ " parameters is near to 1 and the probability values are less than 0.05 . This demonstrates that all models are statistically significant.

In most countries' stock market indices, there is a considerable relationship between price volatility and trading volume, as seen in Table 7. When the " $\rho$ " parameters and their 


\begin{tabular}{|c|c|c|c|c|c|c|}
\hline Countries & ADF test statistics & $1 \%$ & $\begin{array}{c}\text { Test critical values } \\
5 \%\end{array}$ & $10 \%$ & Probability & $\begin{array}{l}\text { A comparison } \\
\text { of international }\end{array}$ \\
\hline Australia & -16.764 & -2.567 & -1.941 & -1.616 & 0.000 & II Ke \\
\hline Austria & -10.817 & -2.567 & -1.941 & -1.616 & 0.000 & \\
\hline Belgium & -11.743 & -2.567 & -1.941 & -1.616 & 0.000 & \\
\hline Brazil & -10.587 & -2.567 & -1.941 & -1.616 & 0.000 & \\
\hline Canada & -9.795 & -2.567 & -1.941 & -1.616 & 0.000 & 99 \\
\hline China & -31.228 & -2.567 & -1.941 & -1.616 & 0.000 & \\
\hline France & -11.424 & -2.567 & -1.941 & -1.616 & 0.000 & \\
\hline Germany & -20.521 & -2.567 & -1.941 & -1.616 & 0.000 & \\
\hline Netherlands & -11.535 & -2.567 & -1.941 & -1.616 & 0.000 & \\
\hline Italy & -15.766 & -2.567 & -1.941 & -1.616 & 0.000 & \\
\hline İreland & -10.643 & -2.567 & -1.941 & -1.616 & 0.000 & \\
\hline Japan & -30.114 & -2.567 & -1.941 & -1.616 & 0.000 & \\
\hline Malaysia & -31.736 & -2.567 & -1.941 & -1.616 & 0.000 & \\
\hline Poland & -30.311 & -2.567 & -1.941 & -1.616 & 0.000 & \\
\hline Portugal & -19.935 & -2.567 & -1.941 & -1.616 & 0.000 & \\
\hline Qatar & -29.720 & -2.567 & -1.941 & -1.616 & 0.000 & \\
\hline South Korea & -18.717 & -2.567 & -1.941 & -1.616 & 0.000 & \\
\hline Spain & -19.623 & -2.567 & -1.941 & -1.616 & 0.000 & \\
\hline Sweden & -32.566 & -2.567 & -1.941 & -1.616 & 0.000 & \\
\hline Switzerland & -32.639 & -2.567 & -1.941 & -1.616 & 0.000 & \\
\hline Tunisia & -25.714 & -2.567 & -1.941 & -1.616 & 0.000 & \\
\hline Turkey & -20.427 & -2.567 & -1.941 & -1.616 & 0.000 & \\
\hline UAE & -16.225 & -2.567 & -1.941 & -1.616 & 0.000 & Table 4. \\
\hline UK & -11.343 & -2.567 & -1.941 & -1.616 & 0.000 & Unit root test results of \\
\hline USA & -9.276 & -2.567 & -1.941 & -1.616 & 0.000 & price series in I (1) form \\
\hline
\end{tabular}

probability values are analyzed, it is observed that there are stock market indices with no significant relationship between trading volume and price changes.

Table 8 lists countries stock exchange indices in terms of the degree of relationship where there is a negative relationship between transaction volume and price changes. Investors in these countries buy stocks when prices fall, while sell orders are executed when prices rise. When the " $\rho$ " parameters of the models are compared, the price-volume relationship in the US market, which is known as the most liquid and has the greatest trading volume, is found to be the strongest. The stock exchange indices of Australia, the United Kingdom, South Korea, Turkey, Canada and Japan follow the US market.

The price-volume relationship, on the other hand, remains low in Eurozone nations such as Spain, France, Germany, the Netherlands, Ireland and Switzerland. The main reason for this is that the COVID-19 pandemic, which broke out in the early half of 2020, caused stock prices to drop. During that time, stock market indices around the world experienced a significant decline, but after the COVID-19 shock was overcome, the closing prices of these stock market indices began to rise. However, as shown in Table 8, trading volume in the nations stated above did not fully support this recovery. But when it comes to China, where the pandemic was most serious, the relationship between price changes and trading volume does not have a negative direction, demonstrating that there is a price anomaly there. As a result, including this country in this group is inappropriate.

Table 9 also includes stock market indexes with a positive relationship between volume and price. There is clearly a price anomaly in these countries. Investors make buying decisions as a result of the optimistic atmosphere that arises when stock prices rise. The pessimistic atmosphere caused by the fall in stock prices, on the other hand, causes investors to sell their stocks. It is determined that the price movements and trading volume 


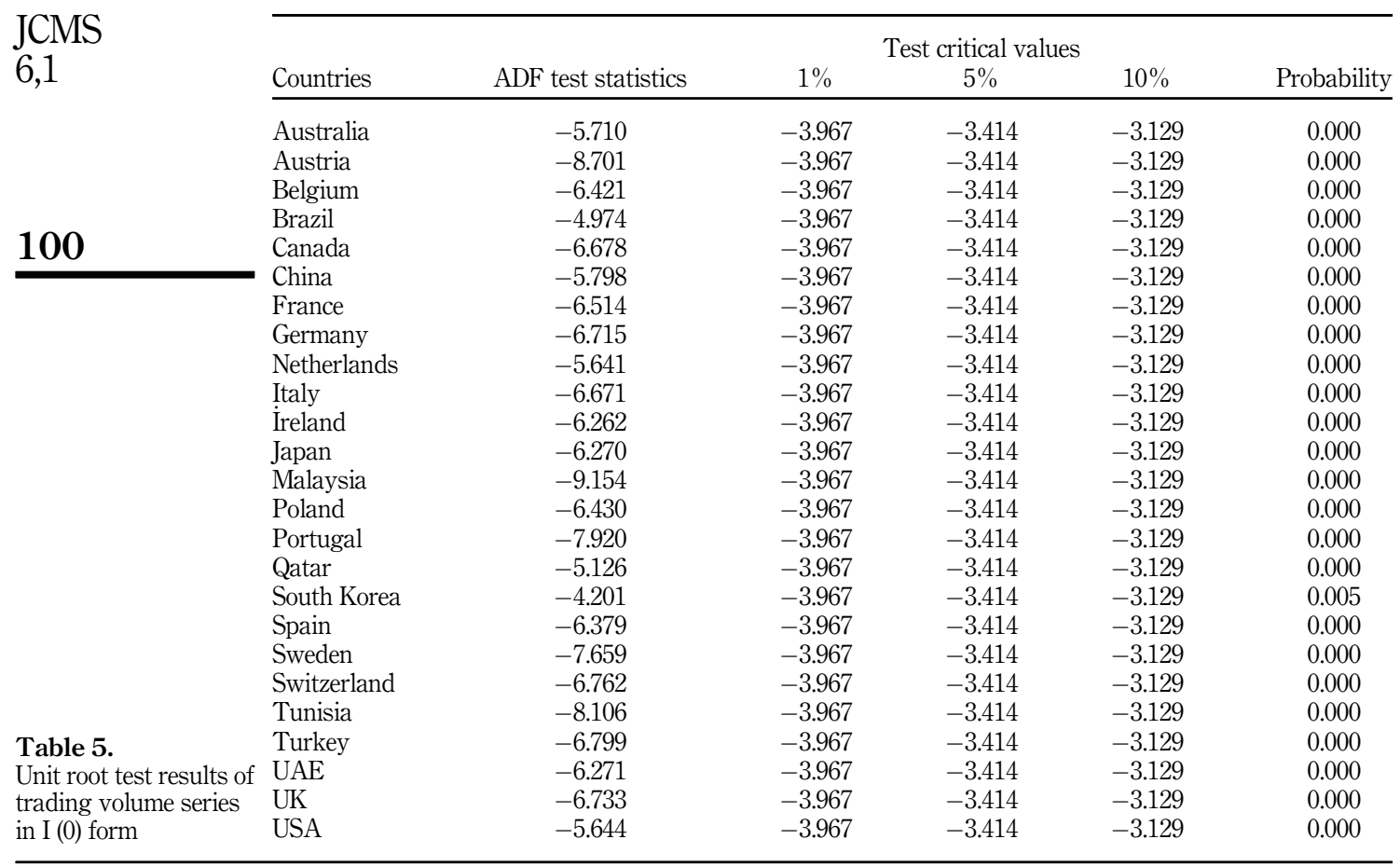

in the stock market indexes of China, the United Arab Emirates and Qatar have a positive relationship from price to volume, based on the parameters of the models and their probability values. China has the strongest price-volume relationship, followed by the UAE and Qatar.

Additionally, no significant relationship between volume and price is observed in capital markets in Sweden, Belgium, Italy, Brazil, Austria, Malaysia, Poland, Tunisia and Portugal. Price changes during the sample period in these countries are not supported by trading volume.

In brief, the study's findings are as follows:

(1) Price changes in the capital markets in 16 of the 25 countries examined have been found to effect trading volume. In the capital markets of the other nine countries, however, no such interaction was detected. The hypothesis "whether price changes in capital markets effect trading volume differs by market condition" can be supported. In summary, considering parameters such as market structure, information flow in the market, financial stability and the examination period, it can be stated if price changes in the trading volume are related or not.

(2) The relationship has been found to be negative in 13 of the 16 nations where transaction volume and price changes are related. To put it another way, when prices rise in these 13 nations, trading volume (demand) falls and vice versa. However, the relationship between trading volume and price changes was found to be positive in three of the 16 nations examined. The hypothesis "whether the relationship between price changes and trading volume is positive or negative depends on market conditions" can be supported. The noise traders hypothesis is valid in three nations, 


\begin{tabular}{|c|c|c|c|c|c|}
\hline & $F$-statistic & Prob & Obs* $R$-squared & Prob. chi-square & A comparison \\
\hline USA & 680.2281 & 0.0000 & 409.5191 & 0.0000 & market \\
\hline Germany & 150.4669 & 0.0000 & 131.4460 & 0.0000 & \\
\hline Australia & 191.0955 & 0.0000 & 161.4787 & 0.0000 & \\
\hline Austria & 16.5483 & 0.0001 & 16.3149 & 0.0001 & \\
\hline Belgium & 71.6951 & 0.0000 & 67.1963 & 0.0000 & \\
\hline UAE & 554.1782 & 0.0000 & 359.2926 & 0.0000 & 101 \\
\hline Brazil & 572.8714 & 0.0000 & 365.6074 & 0.0000 & \\
\hline China & 2307.0380 & 0.0000 & 695.1105 & 0.0000 & \\
\hline France & 468.7451 & 0.0000 & 323.6380 & 0.0000 & \\
\hline South Korea & 503.9492 & 0.0000 & 335.5301 & 0.0000 & \\
\hline Netherland & 339.1115 & 0.0000 & 256.1585 & 0.0000 & \\
\hline UK & 270.4385 & 0.0000 & 214.5282 & 0.0000 & \\
\hline Ireland & 5.9158 & 0.0152 & 5.8935 & 0.0152 & \\
\hline Spain & 55.7043 & 0.0000 & 52.9715 & 0.0000 & \\
\hline Sweden & 600.9607 & 0.0000 & 378.8999 & 0.0000 & \\
\hline Switzerland & 1013.4320 & 0.0000 & 508.6047 & 0.0000 & \\
\hline Italy & 40.1644 & 0.0000 & 38.7307 & 0.0000 & \\
\hline Japan & 519.4259 & 0.0000 & 341.4864 & 0.0000 & \\
\hline Canada & 25.0305 & 0.0000 & 24.4778 & 0.0000 & \\
\hline Qatar & 231.2129 & 0.0000 & 188.5152 & 0.0000 & \\
\hline Malaysia & 13.0138 & 0.0003 & 12.8714 & 0.0003 & \\
\hline Poland & 12.9944 & 0.0003 & 12.8553 & 0.0003 & Table 6. \\
\hline Portugal & 40.2869 & 0.0000 & 38.8578 & 0.0000 & ARCH \\
\hline Tunisia & 7.2145 & 0.0074 & 7.1769 & 0.0074 & heteroscedasticity test \\
\hline Turkey & 1376.0590 & 0.0000 & 587.9223 & 0.0000 & results \\
\hline
\end{tabular}

\begin{tabular}{|c|c|c|c|c|c|c|}
\hline Countries & $\omega$ & $\alpha$ & $r$ & $\beta$ & $\rho$ & \\
\hline Australia & $-1.1252(0.0000)$ & $0.5128(0.0000)$ & $0.1650(0.0000)$ & $0.8070(0.0000)$ & $-0.0182(0.0000)$ & \\
\hline Austria & $-2.2200(0.0000)$ & $0.1536(0.0000)$ & $0.2295(0.0000)$ & $0.8339(0.0000)$ & $-0.0001(0.2027)$ & \\
\hline Belgium & $-1.4072(0.0000)$ & $0.3725(0.0000)$ & $0.0341(0.0505)$ & $0.8767(0.0000)$ & $-0.0005(0.0475)$ & \\
\hline Brazil & $-0.5782(0.0007)$ & $0.2873(0.0000)$ & $0.0283(0.1215)$ & $0.9725(0.0000)$ & $-0.0001(0.0081)$ & \\
\hline Canada & $-0.5921(0.0000)$ & $0.1776(0.0000)$ & $0.0568(0.0000)$ & $0.9154(0.0000)$ & $-0.0080(0.0003)$ & \\
\hline China & $0.1580(0.0247)$ & $0.6195(0.0000)$ & $0.1811(0.0000)$ & $0.7890(0.0000)$ & $0.1954(0.0050)$ & \\
\hline France & $-1.2378(0.0000)$ & $0.2048(0.0000)$ & $0.1018(0.0000)$ & $0.8515(0.0000)$ & $-0.0027(0.0001)$ & \\
\hline Germany & $-3.9957(0.0000)$ & $0.5537(0.0000)$ & $0.2099(0.0000)$ & $0.4995(0.0000)$ & $-0.0020(0.0019)$ & \\
\hline Italy & $-0.5929(0.0000)$ & $0.4439(0.0000)$ & $0.0978(0.0032)$ & $0.9085(0.0000)$ & $-0.0003(0.9532)$ & \\
\hline Ireland & $-3.7359(0.0000)$ & $0.5241(0.0000)$ & $0.7283(0.0000)$ & $0.5913(0.0000)$ & $-0.0014(0.0001)$ & \\
\hline Japan & $-1.0078(0.0000)$ & $0.6070(0.0000)$ & $0.0863(0.0956)$ & $0.8274(0.0000)$ & $-0.0079(0.0875)$ & \\
\hline Malaysia & $-2.0028(0.0000)$ & $0.2884(0.0000)$ & $0.1667(0.0000)$ & $0.6990(0.0000)$ & $0.0006(0.7705)$ & \\
\hline Netherlands & $-1.3550(0.0000)$ & $0.3016(0.0000)$ & $0.1218(0.0000)$ & $0.8461(0.0000)$ & $-0.0019(0.0163)$ & \\
\hline Poland & $-2.3209(0.0000)$ & $0.3830(0.0000)$ & $0.2475(0.0000)$ & $0.7572(0.0000)$ & $0.0005(0.2292)$ & \\
\hline Portugal & $-1.0565(0.0000)$ & $0.3650(0.0000)$ & $0.1411(0.0000)$ & $0.8912(0.0000)$ & $0.0000(0.9856)$ & \\
\hline Qatar & $-0.5063(0.0000)$ & $0.3327(0.0000)$ & $0.0675(0.0001)$ & $0.9737(0.0000)$ & $0.0006(0.0000)$ & \\
\hline South Korea & $-0.8127(0.0000)$ & $0.6191(0.0000)$ & $0.1116(0.0199)$ & $0.9204(0.0000)$ & $-0.0129(0.0008)$ & \\
\hline Spain & $-0.8158(0.0000)$ & $0.2642(0.0000)$ & $0.1399(0.0000)$ & $0.8901(0.0000)$ & $-0.0045(0.0042)$ & \\
\hline Sweden & $-2.5760(0.0000)$ & $0.5136(0.0000)$ & $0.1222(0.0116)$ & $0.7053(0.0000)$ & $-0.0007(0.2339)$ & \\
\hline Switzerland & $-1.1274(0.0000)$ & $0.2106(0.0000)$ & $0.0673(0.0033)$ & $0.8797(0.0000)$ & $-0.0013(0.0247)$ & \\
\hline Tunisia & $-3.3738(0.0000)$ & $0.3399(0.0000)$ & $0.1637(0.0000)$ & $0.8052(0.0000)$ & $0.0000(0.1222)$ & \\
\hline Turkey & $-0.7700(0.0000)$ & $0.8105(0.0000)$ & 0.1047 (0.0488) & $0.9290(0.0000)$ & $-0.0105(0.0942)$ & \\
\hline UAE & $-1.1487(0.0000)$ & $0.4152(0.0000)$ & $0.0931(0.0553)$ & $0.8767(0.0000)$ & $0.0015(0.0467)$ & \\
\hline UK & $-1.6788(0.0000)$ & $0.4428(0.0000)$ & $0.1794(0.0000)$ & $0.5578(0.0000)$ & $-0.0163(0.0073)$ & Table 7 \\
\hline USA & $-0.3908(0.0000)$ & $0.4030(0.0000)$ & $0.0912(0.0004)$ & $0.8956(0.0000)$ & $-0.0813(0.0000)$ & EGARCH results \\
\hline
\end{tabular}


JCMS

6,1

\begin{tabular}{lcc}
\hline & $\rho$ & Price-volume relation \\
\hline 1. USA* & -0.081272 & Significant \\
2. Australia* & -0.018193 & Significant \\
3. UK* & -0.016280 & Significant \\
4. South Korea* & -0.012901 & Significant \\
5. Turkey* & -0.010498 & Significant \\
6. Canada* & -0.008003 & Significant \\
7. Japan* & -0.007868 & Significant \\
8. Spain* & -0.004522 & Significant \\
9. France* & -0.002663 & Significant \\
10. Germany* & -0.001970 & Significant \\
11. Netherlands* & -0.001889 & Significant \\
12. Ireland* & -0.001413 & Significant \\
13. Switzerland* & -0.001342 & Significant \\
14. Sweden** & -0.000734 & Insignificant \\
15. Belgium** & -0.000527 & Insignificant \\
16. Italy** & -0.000314 & Insignificant \\
17. Brazil** & -0.000064 & Insignificant \\
18. Austria** & -0.000059 & Insignificant
\end{tabular}

Table 8.

Rankings of stock exchange indices with negative relationship between transaction volume and price changes
Note(s): *Countries with a significant relationship between trading volume and volatility. $* *$ Countries where no statistically significant relationship could be found between trading volume and volatility

\begin{tabular}{lcc}
\hline & $\rho$ & Price-volume relation \\
\hline 1. China* & 0.195446 & Significant \\
2. UAE* & 0.001421 & Significant \\
3. Qatar* & 0.000600 & Significant \\
4. Malaysia** & 0.000569 & Insignificant \\
5. Poland** & 0.000492 & Insignificant \\
6. Tunisia** & 0.000033 & Insignificant \\
7. Portugal** & 0.000014 & Insignificant
\end{tabular}

Note(s): *Countries with a significant relationship between trading volume and volatility. **Countries where no statistically significant relationship could be found between trading volume and volatility

while a price demand mechanism analogous to the classical law of demand is observed in thirteen.

(3) All of the " $\omega$ " parameters in the 25 models developed have negative values, according to the findings. In this case, the hypothesis "there is an asymmetry in the relationship between price and volume in terms of falling or rising price" is supported.

(4) The effect of price changes on trading volume can also be used to compare market efficiency levels. In EGARCH models, statistically significant " $p$ " parameters show how much price changes effect trade volume. By ranking these parameters the efficiency levels of the market can also be listed. In fact, the size of the price-volume relationship can be used to determine how much new information entering the market reflects market participants' action and how homogenous respond of market actors to this information. In this case, the greater is relationship between price and volume, the more predictable and efficient is the market. 


\section{Conclusion}

Critical information about the market structure can be obtained by evaluating the degree and direction of the volume-price relationship in capital markets. In fact, the price-volume relationship includes critical information about a market structure and answers questions like how the market's information flow reflects prices, whether there is an asymmetry in the information flow, whether there is a speculative pricing problem and whether there are trading restrictions in a market.

As a result, a relationship from stock prices to trading volume is found in this analysis. The existence, size and direction of this relationship, on the other hand, are dependent on the market's structure and efficiency level. As a result of the results of this study, it is possible to comment on a market's level of efficiency by measuring the price-volume relationship in the capital markets.

According to the study's findings, investors are advised to examine the price-volume relationship in a market before beginning to trade in that market. In this way, investors can understand about the market's efficiency and whether it is overpriced.

The study's most significant limitation is that it is difficult to ascertain a definitive conclusion about the subject under investigation. In reality, if the same research is done using data from different countries and time periods, the results are quite likely to vary. However, in the future studies, similar analyses can be done with shorter or longer-term data, sectoral data on a specific market and data from capital markets and commodities markets on the issue, in order to identify their structural differences.

\section{References}

Akerlof, G.A. (1970), “The market for 'lemons': quality uncertainty and the market mechanism”, The Quarterly Journal of Economics, Vol. 84 No. 3, pp. 488-500.

Al-Deehani, T.M. (2007), "Modeling asymmetry in the price-volume relation: evidence from nine stock markets", Investment Management and Financial Innovations, Vol. 4 No. 4, pp. 8-15.

Alizadeh, A.H. and Tamvakis, M. (2016), "Market conditions, trader types and price-volume relation in energy futures markets", Energy Economics, Vol. 56, pp. 134-149.

Ananzeh, I.E.N., Jdaitawi, Q.M. and Al-Jayousi, A.M. (2013), "Relationship between market volatility and trading volume: evidence from Amman stock exchange", International Journal of Business and Social Science, Vol. 4 No. 16, pp. 188-198.

Assogbavi, T. and Osagi, J.E. (2006), "Equity valuation process and price-volume relationship on emerging stock markets", International Business and Economics Research Journal, Vol. 5 No. 9, pp. 7-18.

Boyacıoğolu, M.A., Güvenek, B. and Alptekin, V. (2010), "Getiri volatilitesi ile işlem hacmi arasındaki ilişki: İMKB'de ampirik bir çalışma”, Muhasebe ve Finansman Dergisi, Vol. 48, pp. 200-215.

Campbell, J.Y., Grossman, S.J. and Wang, J. (1993), "Trading volume and serial correlation in stock returns", The Quarterly Journal of Economics, Vol. 108 No. 4, pp. 905-939.

Chen, S.S. (2012), "Revisiting the empirical linkages between stock returns and trading volume", Journal of Banking and Finance, Vol. 36 No. 6, pp. 1781-1788.

Chen, G., Firth, M. and Rui, O. (2001), "The dynamic relation between stock returns, trading volume, and volatility", The Financial Review, Vol. 36 No. 3, pp. 153-174.

Ciner, C. (2015), "Time variation in systematic risk, returns and trading volume: evidence from precious metals mining stocks", International Review of Financial Analysis, Vol. 41, pp. 277-283.

Clark, P.K. (1973), "A subordinated stochastic process model with finite variance for speculative prices”, Econometrica, Vol. 41, pp. 135-155.

Copeland, T.E. (1976), "A model of asset trading under the assumption of sequential information arrival”, Journal of Finance, Vol. 31, pp. 1149-1168.

A comparison of international market 
JCMS 6,1

Çukur, S., Gümrah, Ü. and Gümrah, M. (2012), "İstanbul menkul kıymetler borsasında hisse senedi getirileri ve işlem hacmi ilişkisi”, Niğde Universitesi İktisadi ve İdari Bilimler Fakültesi Dergisi, Vol. 5 No. 1, pp. 20-35.

De Long, J.B., Shleifer, A., Summers, L.H. and Waldmann, R.J. (1990), "Noise trader risk in financial markets", The Journal of Political Economy, Vol. 98 No. 4, pp. 703-738.

Elmas, B. and Yıldırım, M. (2010), "Kriz dönemlerinde hisse senedi fiyatı ile ișlem hacmi ilișkisi: IMKB'de işlem gören bankacllk sektör hisseleri üzerine bir uygulama”, Atatürk Üniversitesi Ítisadi ve İdari Bilimler Dergisi, Vol. 24 No. 2, pp. 37-46.

Epps, T.W. and Epps, M.L. (1976), "The stochastic dependence of security price changes and transaction volumes: implications for the mixture-of-distributions hypothesis", Econometrica, Vol. 44, pp. 305-321.

Erdem, K., Koy, A. and Akdağ, S. (2020), "Pay endekslerinde en yüksek fiyat oluşumu ile işlem hacmi arasındaki ilişki: doğrusal analizler ve frekans alanı nedensellik analizi ile karşılaştırmalı bir yaklaşım”, Uluslararası Ekonomi ve Yenilik Dergisi, Vol. 6 No. 2, pp. 157-173.

Fama, E.F. (1970), "Efficient capital markets: a review of theory and empirical work", The Journal of Finance, Vol. 25 No. 2, pp. 383-417.

Gazel, S. (2017), "Hisse senedi piyasalarında işlem hacmi ve volatilite ilişkisi: Kırılgan beşli ekonomiler üzerine bir inceleme”, Uluslararası Yönetim İktisat ve İşletme Dergisi, Vol. 13 No. 2, pp. 347-363.

Gebka, B. and Wohar, M.E. (2013), "Causality between trading volume and returns: evidence from quantile regressions", International Review of Economics and Finance, Vol. 27, pp. 144-159.

Gökçe, A. (2002), “IMKB'de fiyat-hacim ilişkisi: Granger nedensellik testi”, Gazi Üniversitesi İIBF Dergisi, Vol. 4 No. 3, pp. 43-48.

Harris, L. (1986), "Cross-security tests of the mixture of distributions hypothesis", Journal of Financial Quantitative Analysis, Vol. 21, pp. 39-46.

Jain, P.C. and Joh, G.H. (1988), "The dependence between hourly prices and trading volume", The Journal of Financial and Quantitative Analysis, Vol. 23 No. 3, pp. 269-283.

Karpoff, J.M. (1987), "The relation between price changes and trading volume: a survey", The Journal of Financial and Quantitative Analysis, Vol. 22 No. 1, pp. 109-126, doi: 10.2307/2330874.

Kayalıdere, K. and ve Aktaş, H. (2009), “iMKB'de fiyat-hacim ilişkisi - asimetrik etkileşim”, Celal Bayar Üniversitesi İktisadi ve İdari Bilimler Dergisi, Vol. 16 No. 2, pp. 49-62.

Kıran, B. (2010), “İstanbul Menkul Kıymetler Borsa'sında getiri volatilitesi ve işlem hacmi”, Doğuş Üniversitesi Dergisi, Vol. 11 No. 1, pp. 98-108.

Lee, B.S. and Rui, O.M. (2002), "The dynamic relationship between stock returns and trading volume: domestic and cross-country evidence", Journal of Banking and Finance, Vol. 26, pp. 51-78.

Marsh, T. and Wagner, N. (2004), "Return-volume dependence and extremes in international equity markets", available at SSRN: https://papers.ssrn.com/sol3/papers.cfm?abstract_id=424926.

Martikainen, T., Puttonen, V., Luoma, M. and Rothovius, T. (1994), "The linear and non-linear dependence of stock returns and trading volume in the Finnish stock market", Applied Financial Economics, Vol. 4 No. 2, pp. 159-169.

Nalın, H.T. and Güler, S. (2013), "İstanbul Menkul Kıymetler Borsası'nda işlem hacmi ile getiri ilişkisi”, Muhasebe ve Finansman Dergisi, No. 59, pp. 135-148.

Nyakurukwa, K. (2021), "Revisiting the dynamic stock return-volume relationship in South Africa: a non-parametric causality in quantiles approach", Macroeconomics and Finance in Emerging Market Economies, pp. 1-17, doi: 10.1080/17520843.2021.1953865.

Saatçioğlu, K. and Starks, L.T. (1998), "The stock price-volume relationship in emerging stock markets: the case of Latin America”, International Journal of Forecasting, Vol. 14 No. 2, pp. 215-225. 
Silvapulle, P. and Choi, J. (1999), "Testing for linear and nonlinear Granger causality in the stock pricevolume relation: Korean evidence", The Quarterly Review of Economics and Finance, Vol. 39 No. 1, pp. 59-76.

Tauchen, G.E. and Pitts, M. (1983), "The price variability-volume relationship on speculative markets",

A comparison of international market Econometrica Journal of the Economic Society, Vol. 51 No. 2, pp. 485-505.

Umutlu, G. (2008), "Işslem hacmi ve fiyat değişimleri arasındaki nedensellik ve dinamik ilişkiler: IMKB'de bir ampirik inceleme”, Gazi Üniversitesi İktisadi ve İdari Bilimler Fakültesi Dergisi, Vol. 10 No. 1, pp. 231-246.

Yılancı, V. and ve Bozoklu, Ş. (2014), "Türk sermaye piyasasında fiyat ve ișlem hacmi ilişkisi: Zamanla değişen asimetrik nedensellik analizi”, Ege Akademik Bakış, Vol. 14 No. 2, pp. 211-220.

Zada, R.S.E. (2021), "The relationship between trading volume 'stock returns' and volatility in the Saudi stock market”, Qalaai Zanist Scientific Journal, Vol. 6 No. 3, pp. 790-822.

\section{Corresponding author}

Sunay Çıralı can be contacted at: sunay.cirali@gmail.com

For instructions on how to order reprints of this article, please visit our website: 